\title{
QUALITY CONTROL PROCEDURES APPLIED TO ROUTINE ELECTRON PROBE ANALYSES OF KIMBERLITE INDICATOR MINERALS
}

\author{
De Bruin D1 and Gräser P2 \\ 1. Diamond Indicator Minerals Pty Ltd, P.O. Box 19, Bull Creek, 6149, WA, Australia \\ 2. Department of Geology, University of Pretoria, Pretoria, South Africa
}

Routine electron miro-probe analyses (EMPA) of kimberlite indicator minerals, have been subjected to a rigorous quality control method whereby monitor grains were analysed at set periods within analytical runs. These methods have been applied for several tens of thousands analyses such as data described by Rogers and Grütter (2009). The procedure that is used provides a check method to show that results of different sample batches are consistent with respect to one another, that analyses are done under optimum conditions and that a procedure was in place to detect the occurrence of abnormal or unexpected events that could affect results.

The desirable qualities of monitor grains for kimberlite indicator minerals are that the material should have compositions that include detectable levels of all elements routinely analyzed by EMPA, be homogenous, be available in sufficient quantities and have a similar appearance to the unknown samples. Materials that fulfill the above criteria for EMPA of kimberlite indicator minerals are not freely available. The reference standards described by Jarosewich (1980), were prepared in very limited quantities and are used as the primary calibration standards. Other possible reference materials, that are available in suitable quantities, are glass samples used for round robin analytical samples (Potts et al., 2002). These samples have a distinctly different composition and appearance to kimberlite indicator minerals. This makes them unsuitable monitor materials.
Suitable material was selected from kimberlitic megacrysts for clinopyroxene and ilmenite and chromite from an ophiolite.

Clinopyroxene, CPX3 and ilmenite, WIL5 are megacrysts from the Premier, Schuller and Witberg kimberlites, and described and analyses provided by De Bruin (1993, 2005). Quality control results for garnet $\mathrm{P} 1$, are given by provided De Bruin (2010).

The large size of the specimens ensured that sufficient material were available for the study and it was found to have detectable concentrations of the elements normally analyzed by EPMA for kimberlite indicator minerals. The garnet sample discussed by De Bruin (2010), was chosen as it contained measurable concentration of $\mathrm{Na} 2 \mathrm{O}$ which is critical for the evaluation of diamond eclogite potential when using kimberlite garnets. Due to the general absence of large homogenous chromite grains in kimberlites, suitable material was obtained from a podiform chromite from the Luobusa ophiolite described by Yamomoto et al. (2009).

Analyses were done with a Cameca SX100 electron micro-probe at the University of Pretoria, South Africa. Analyses were conducted with WDS using an accelerating voltage of $20 \mathrm{kV}$, a beam current of $20 \mathrm{nA}$ and a nominal beam diameter of 3 microns. Major and minor elements were analyzed on $\mathrm{K}$ emission lines. Counting times of 10 and 5 seconds were used on the peak and background positions respectively. Detection 


\section{$1^{\text {th }}$ International Kimberlite Conference, Bangalore - 2012}

limits were determined to be approximately 0.05 $\% \mathrm{~m} / \mathrm{m}$ for all elements except for $\mathrm{Na}$ where a detection limit of $0.03 \% \mathrm{~m} / \mathrm{m}$ was achieved with 30 and 15 second counting times on a high sensitivity TAP diffracting crystal. The calibration standards included Kakanui pyrope, Kakanui hornblende, diopside Natural Bridge and chromite Teigbagi Mine described by Jarosewich et al. (1980), synthetic rutile and natural rhodonite obtained from Imperial College, London (Dick Rickard, pers. comm. 1986).

The monitor samples were routinely analyzed as fixed grains set on the sample holder and as grains mounted with routine samples. Statistics obtained from the results of multiple analyses on sample monitor grains are presented for clinopyroxene, ilmenite and chromite (Tables 1 to 3$)$.

Table - 1 Analyses for clinopyroxene CPX3 disk monitor samples.

\begin{tabular}{lllll}
\hline \multicolumn{5}{c}{$\mathrm{CPX} 3 \mathrm{n}=50$} \\
\hline & mean & 1SD & \%RSD & mean $\pm 2 \mathrm{SD}$ \\
\hline $\mathrm{SiO}$ & 54.90 & 0.42 & 0.76 & $55.74-54.07$ \\
$\mathrm{MgO}$ & 22.14 & 0.40 & 1.83 & $22.95-21.33$ \\
$\mathrm{CaO}$ & 11.85 & 0.46 & 3.86 & $12.77-10.94$ \\
$\mathrm{FeOT}$ & 6.06 & 10.17 & 2.79 & $6.40-5.72$ \\
$\mathrm{Al}_{2} \mathrm{O}_{3}$ & 2.56 & 0.07 & 2.86 & $2.70-2.41$ \\
$\mathrm{Na}_{2} \mathrm{O}$ & 1.49 & 0.06 & 4.31 & $1.62-1.36$ \\
$\mathrm{TiO}_{2}$ & 0.23 & 0.03 & 12.03 & $0.29-0.18$ \\
$\mathrm{Cr}_{2} \mathrm{O}_{3}$ & 0.27 & 0.03 & 9.27 & $0.32-0.22$ \\
$\mathrm{MnO}^{2}$ & 0.14 & 0.02 & 16.51 & $0.18-0.09$ \\
\hline
\end{tabular}

Table - 2 Analyses for chromite LA326 disk monitor samples.

\begin{tabular}{lllll}
\hline \multicolumn{5}{c}{ LA326 $\mathrm{n}=50$} \\
\hline & mean & 1SD & \%RSD & mean $\pm 2 \mathrm{SD}$ \\
\hline $\mathrm{Cr}_{2} \mathrm{O}_{3}$ & 59.40 & 1.13 & 1.90 & $61.65-57.144$ \\
$\mathrm{MgO}$ & 15.30 & 0.42 & 2.76 & $16.14-14.45$ \\
$\mathrm{Al}_{2} \mathrm{O}_{3}$ & 10.60 & 0.54 & 5.09 & $11.68-9.52$ \\
$\mathrm{FeOT}$ & 12.29 & 0.34 & 2.79 & $12.98-11.60$ \\
$\mathrm{MnO}$ & 0.23 & 0.03 & 12.33 & $0.29-0.18$ \\
$\mathrm{TiO}_{2}$ & 0.25 & 0.03 & 10.26 & $0.31-0.20$ \\
\hline
\end{tabular}

Table - 3 Analyses for ilmenite WIL5 disk monitor samples.

\begin{tabular}{lllll}
\hline \multicolumn{5}{c}{ WIL5 $\mathrm{n}=33$} \\
\hline & mean & 1SD & \%RSD & mean \pm 2SD \\
$\mathrm{TiO}_{2}$ & 50.95 & 0.35 & 0.70 & $51.66-50.24$ \\
$\mathrm{FeOT}$ & 37.57 & 0.61 & 1.64 & $38.80-36.34$ \\
$\mathrm{MgO}$ & 9.25 & 0.34 & 3.69 & $9.93-8.57$ \\
$\mathrm{Al}_{2} \mathrm{O}_{3}$ & 0.37 & 0.03 & 8.83 & $0.44-0.31$ \\
$\mathrm{Cr}_{2} \mathrm{O}_{3}$ & 0.33 & 0.03 & 8.20 & $0.39-0.28$ \\
$\mathrm{MnO}$ & 0.24 & 0.03 & 11.63 & $0.29-0.18$ \\
$\mathrm{Nb}_{2} \mathrm{O}_{5}$ & 0.13 & 0.05 & 37.27 & $0.23-0.03$ \\
\hline
\end{tabular}

The data can be used as independent control limits for results. Evaluation monitor grains were also analysed at several laboratories using different instruments (Cameca, Jeol), methods (WDS, energy dispersive spectrometry), operating conditions (e.g. $\mathrm{kV}$ and $\mathrm{mA}$ settings) and calibration standards to compare the externally analyzed results with those obtained in this study. Results from several laboratories, using a variety of instruments, and calibration procedures, provide similar values to those found for the disk monitor evaluations in this study and are listed in Tables 4 to 6 .

Table - 4 Inter Laboratory Comparison analyses of CPX3.

\begin{tabular}{|c|c|c|c|c|c|}
\hline \multicolumn{6}{|c|}{ Clinopyroxene - CPX3 } \\
\hline$\overline{\mathrm{Lab}}$ & 1 & 2 & 3 & 4 & 5 \\
\hline $\mathrm{SiO}_{2}$ & 55.38 & 55.71 & 55.74 & 54.50 & 55.40 \\
\hline $\mathrm{TiO}_{2}^{2}$ & 0.24 & 0.29 & 0.21 & 0.20 & 0.20 \\
\hline $\mathrm{Al}_{2} \mathrm{O}_{3}$ & 2.53 & 2.49 & 2.47 & 2.59 & 2.32 \\
\hline $\mathrm{Cr}_{2}^{2} \mathrm{O}_{3}^{3}$ & 0.26 & 0.31 & 0.27 & 0.26 & 0.20 \\
\hline $\mathrm{FeOT}$ & 5.87 & 6.20 & 5.98 & 6.04 & 6.33 \\
\hline $\mathrm{MnO}$ & 0.16 & 0.16 & 0.18 & 0.17 & 0.21 \\
\hline $\mathrm{MgO}$ & 21.32 & 21.45 & 21.85 & 22.10 & 21.73 \\
\hline $\mathrm{CaO}$ & 12.03 & 11.74 & 11.86 & 11.72 & 12.20 \\
\hline $\mathrm{Na}_{2} \mathrm{O}$ & 1.54 & 1.82 & 1.53 & 1.54 & 1.52 \\
\hline TOTAL & 99.37 & 100.21 & 100.12 & 99.12 & 100.11 \\
\hline
\end{tabular}


Table - 5 Inter-laboratory comparison analyses for LA326.

\begin{tabular}{llllll}
\hline \multicolumn{5}{c}{ Chromite - LA326 } \\
\hline $\mathrm{Lab}$ & 1 & 2 & 3 & 4 & 5 \\
$\mathrm{SiO}_{2}$ & 0.00 & 0.00 & 0.00 & 0.00 & 0.00 \\
$\mathrm{TiO}_{2}$ & 0.24 & 0.26 & 0.20 & 0.29 & 0.22 \\
$\mathrm{Al}_{2} \mathrm{O}_{3}$ & 10.72 & 10.65 & 9.81 & 10.95 & 10.39 \\
$\mathrm{Cr}_{2} \mathrm{O}_{3}$ & 59.15 & 60.63 & 61.31 & 60.07 & 61.30 \\
$\mathrm{FeOT}$ & 12.45 & 12.60 & 12.45 & 11.92 & 12.17 \\
$\mathrm{MnO}$ & 0.14 & 0.22 & 0.21 & 0.26 & 0.00 \\
$\mathrm{MgO}$ & 16.52 & 14.88 & 16.00 & 15.79 & 15.36 \\
$\mathrm{CaO}$ & 0.00 & 0.00 & 0.00 & 0.00 & 0.00 \\
$\mathrm{Na}$ & & & 0.02 & & \\
\hline $\mathrm{TOTAL}$ & 99.73 & 99.48 & 100.59 & 99.55 & 99.65 \\
\hline
\end{tabular}

Table - 6 Inter-laboratory comparison analyses for WIL5

\begin{tabular}{llllll}
\hline \multicolumn{7}{c}{ Ilmenite -WIL5 } \\
\hline $\mathrm{Lab}$ & 1 & 2 & 3 & 4 & 5 \\
$\mathrm{SiO}_{2}$ & 0.00 & 0.30 & 0.00 & 0.00 & 0.00 \\
$\mathrm{TiO}_{2}$ & 50.52 & 50.10 & 51.82 & 50.95 & 51.47 \\
$\mathrm{Al}_{2} \mathrm{O}_{3}$ & 0.38 & 0.56 & 0.43 & 0.41 & 0.36 \\
$\mathrm{CrO}$ & 0.28 & 0.38 & 0.32 & 0.38 & 0.48 \\
$\mathrm{TFeO}$ & 38.08 & 38.50 & 37.24 & 37.22 & 38.43 \\
$\mathrm{MnO}$ & 0.25 & 0.23 & 0.26 & 0.21 & 0.17 \\
$\mathrm{MgO}$ & 9.56 & 9.09 & 9.91 & 9.20 & 8.79 \\
$\mathrm{CaO}$ & 0.00 & 0.00 & 0.06 & 0.00 & 0.00 \\
\hline TOTAL & 100.48 & 100.49 & 101.15 & 99.34 & 100.59 \\
\hline
\end{tabular}

A number of mounts containing a selection of garnet, clinopyroxene, ilmenite and chromite grains covering the range of typical kimberlite indicator minerals were prepared and analysed at several laboratories. These samples are useful to assess the quality of kimberlite indicator mineral results over a large relevant compositional range from specific laboratories and can also serve as a test of laboratory sample turnaround. These results are suitable to plot on standard kimberlite evaluation diagrams and contain values for key elements, in suitable concentration ranges that are typically used to classify indicator minerals from different mantle lithologies and are shown for garnet, chromite and ilmenite compositions contained in disk SMID0004.

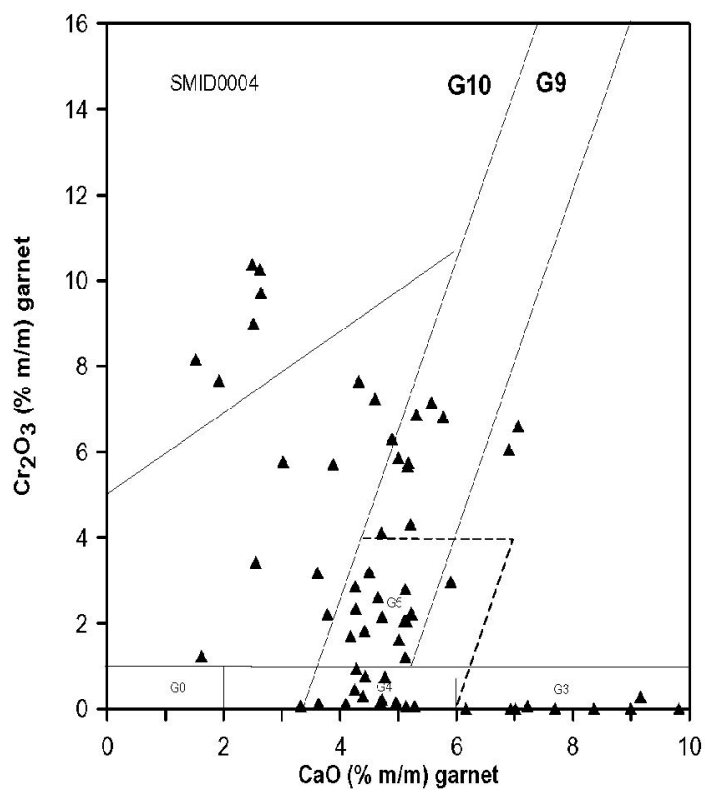

Fig. $1 \mathrm{CaO}$ vs. $\mathrm{Cr} 2 \mathrm{O} 3$ compositions of garnets grains in disk SMID0004.

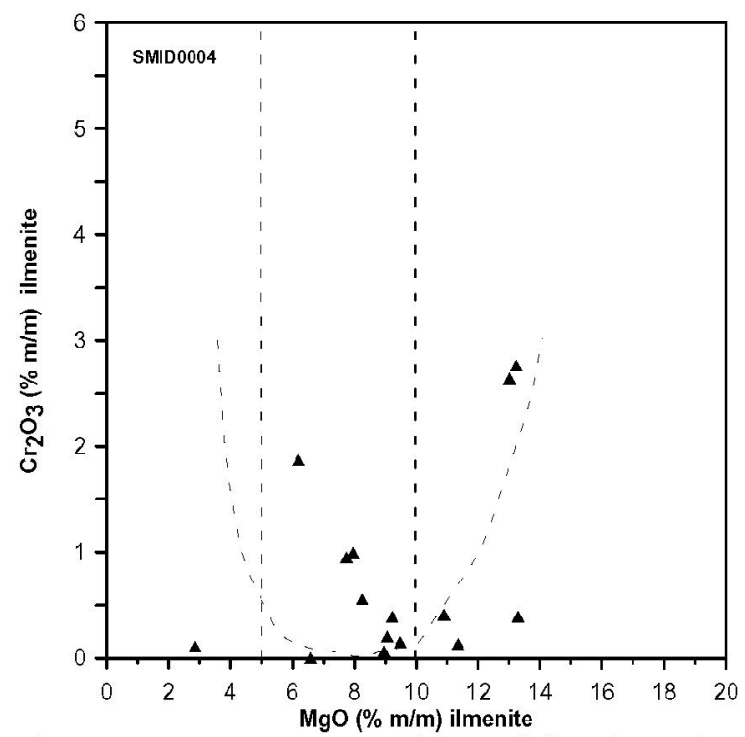

Fig. $2 \mathrm{MgO}$ vs. $\mathrm{Cr} 2 \mathrm{O} 3$ compositions of chromite grains in disk SMID0004

\section{References}

material for the routine electron probe microanalyses of kimberlite exploration garnets. Geostandards and Geoanalytical Research, 34, 257-264. 


\section{0 $^{\text {th }}$ International Kimberlite Conference, Bangalore - 2012}

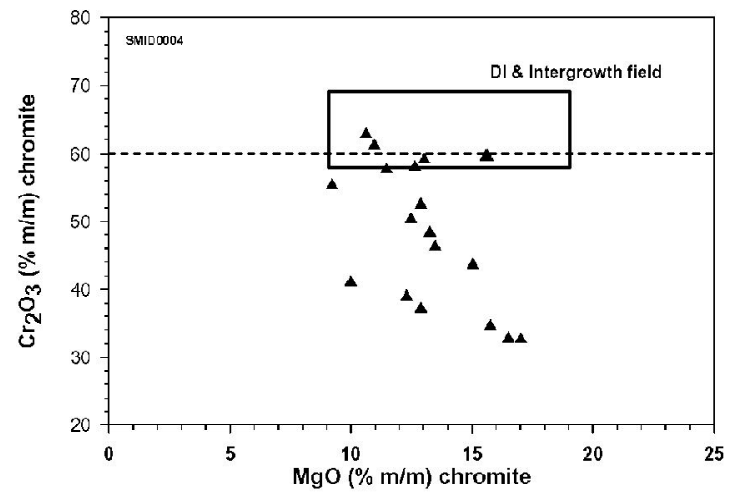

Fig. $3 \mathrm{CaO}$ vs. $\mathrm{Cr} 2 \mathrm{O} 3$ compositions of ilmenite grains in disk $\mathrm{Cr} 2 \mathrm{O} 3(\% \mathrm{~m} / \mathrm{m})$ garnet SMID0004.

De Bruin, D (2005) Multiple compositional megacryst groups from the Uintjiesberg and Witberg kimberlites, South Africa. South African Journal for Geology, 108, 229-242.
De Bruin, D (1993) The megacryst suite from the Schuller kimberlite, South African. Geological Survey of South Africa, Bulletin 114, 112p.

Jarosewich, E, Nelen, J.A and Norberg, J.A (1980).Reference standards for electron microprobe analysis, Geostandards Newsletter, 4, 43-47.

Potts, P.J Thompson M and Wilson, S. (2002) G-Probe1 - An International Proficiency Test for Microprobe Laboratories - Report on Round 1 : February 2002 (TB-1 Basaltic Glass) Geostandards and Geoanalytical Research, 26, $197-235$.

Rogers, A.J.and Grütter, H.S (2009) Fe-rich and Na-rich megacryst clinopyroxene and garnet from Luxinga kimberlte cluster, Lunda Sul, Angola. Lithos, 112S, 942-950.

Yamamoto, S, Komiya, T, Hirose, K and Maroyama, S. (2009) Coesite and clinopyroxene exsolution lamellae in chromites: In situ ultrahigh-pressure evidence for podiform chromitites in the Luobusa ophiolite, south Tibet. Lithos, 109, pp314-322. 